\title{
Pravni problemi regulacije področja političnih strank pri nas in $v$ EU
}

\author{
UDK: 329 (497.12): $341 \mathrm{EU}$
}

\section{Mik Strmecki}

Univerza v Ljubljani, Fakulteta za upravo

mik.strmecki@fu.uni-lj.si

\section{IZVLEČEK}

V članku obravnavamo različna vprašanja, povezana $s$ pravno regulacijo področja političnih strank. Predhodni pravni problem, ki ga mora v zvezi s tem rešiti pravna regulativa, je prvenstveno ustrezno zakonsko definiranje pojma politične stranke zaradi lažjega razmejevanja od pojmovno podobnih subjektov, zlasti društev ipd. Norme s področja političnih strank podrobneje opisujejo pogoje za registracijo politične stranke, statutarni kogentni zakonski okvir, programske omejitve iz naslova varstva temeljev ustavnega reda svobodne demokratične ustavne ureditve, taksativni seznam zakonitih virov financiranja in pravila za primer prenehanja oziroma samorazpustitve politične stranke.

Te norme obsegajo tudi strankarski jurisdikcijski privilegij, da je izključno ustavno sodišče pooblaščeno za razsojo vprašanja eventualne protiustavnosti delovanja političnih strank kot podlage za njihovo prepoved.

V nadaljevanju obravnavamo mejnike v razvoju pravnega položaja političnih strank $v$ posameznih državah EU in vprašanje konstitucionalizacije materije političnih strank v ustavno besedilo.

Sklepno tudi na kratko tematiziramo pravno naravo nalog političnih strank kot determinacijskega elementa za konceptualizacijo izhodišč pravne ureditve njihovega financiranja, financiranja volilnih kandidatov in volilnih kampanj.

Ključne besede: politične stranke, pravne norme s področja političnih strank, konstitucionalizacija strank, taksonomija funkcij političnih strank

\section{Pojem politične stranke in pravne norme}

Kakor velja, da iz načela nacionalne suverenosti izhaja demokratično pooblastilo ljudstvu, da si samo oblikuje svojo državno oblast, velja tudi logična razširitev tega pooblastila na organizacije, ustanovljene s ciljem, da se omogoči avtonomno tvorjenje ljudske volje, tj. razširitev na organizacije, ki lahko pripomorejo k temu, da ljudska volja pride do učinkovitega izraza.

$\checkmark$ normativnem smislu tvorijo torej norme $s$ področja političnih strank zgolj posebno podpodročje normativnega področja ljudske suverenosti in s tem osrednji strukturni element demokratičnega načela.

Pravne norme s področja političnih strank imajo za predmet pravno varstvo političnih strank kot pravnih tvorb in varstvo njihove politične akcijske zmožnosti. 


\section{Mik Strmecki}

\section{Pravni problemi regulacije področja političnih strank}

Obstajajo številne definicije političnostrankarskega fenomena, med katerimi je zanimiva zlasti Ogrisova definicija, da so politične stranke politične organizacije, vključujoče ljudi z istim političnim prepričanjem, ki se borijo za institucionalno osvojitev ali ohranitev oblasti, oziroma če parafraziramo Ogrisa, gre natančneje za osvojitev ali ohranitev njihovega vpliva na državno oblast, prek katere želijo uresničiti svoje politične cilje (Ogris, 1927, str. 8).

Nemški teoretik Grewe opredeljuje pojem politične stranke kot združenje, ki ima za cilj svoje stremljenje po politični oblasti legitimirati kot skupno voljo naroda (Grewe, 1950, str. 43).

Politično stranko je italijanski teoretik Paolo Biscaretti di Ruffia označil kot združenje, ki ima lastnosti privatnega društva, katerega dejavnost zadeva javno sfero; po njegovem gre za združenje, ki se lahko označi $v$ akcijskem smislu kot zasebno izvrševanje javnopravnih funkcij (Biscaretti di Ruffia, 1965, str. 764).

Do natančnejše definicije politične stranke vodijo različne poti. Ena od njih je način, na podlagi katerega je političnim strankam po pravu dopuščeno dokopati se do politične oblasti oziroma jo ohranjati v svojih rokah. Pri tem moramo biti pozorni na kvalitativni obrat pri vsem tem rezoniranju, saj strictu iure oblasti ne izvršujejo več politične stranke, temveč državni poslanci v parlamentu, ki so nekako de iure privatorum povezani s svojo politično stranko, kar pa nima neposredne javnopravne konotacije. Pri navedenih definicijah je srž argumentacije, da mora biti pri političnih strankah že iz definicije razvidna omejitev, da se smejo namreč politične stranke dokopati do svojega cilja izključno na demokratičen način.

Demokratična pot predpostavlja vpliv političnih strank na državno politiko, sorazmeren njihovemu uspehu na volitvah, kar z drugimi besedami pomeni, da vzamemo kot pojmovni dejavnik in kriterij za njihovo pojmovno opredelitev njihovo udeležbo na volitvah, kar mora biti izraz resnega namena prevzeti odgovornost za početje za čas, ko enkrat prevzamejo kontrolo nad državnim krmilom, skratka, odgovornost za odločitve, nastale v njihovi režiji.

Nemški teoretik Kaiser opredeljuje politično stranko kot združenje državljanov, ki imajo za cilj uveljavljanje javnega interesa in ki so tudi trajno organizirane na podlagi nekega združevalnega načela oziroma načel, o katerih je doseženo predhodno soglasje. Ob tem velja pogoj, da se združenje tudi trajno udeležuje volitev s ciljem prevzeti oblast in odgovornost zanjo pred volilnim telesom $v$ celoti, tj. pred narodom (Kaiser, 1956, str. 24).

Po mnenju teoretika Kaiserja je odgovornost odločilni kriterij, kar izvaja iz trditve, da pomeni že postavitev volilnih kandidatov zadosten, učinkovit in konkreten izkaz volje in pripravljenosti politične stranke za prevzem lastne odgovornosti za izvajanje državne oblasti. Podobno trdijo še nekateri nemški teoretiki, kot so Hesse (1967, str. 27), Hering (1967, str. 8), Seifert (1975, str. 2) in Menger (1952, str. 160). 


\section{Pravni problemi regulacije področja političnih strank}

Nemški teoretik Liermann opredeljuje politično stranko kot združenje ljudi, ki si predvsem prizadeva na podlagi volitev pridobiti politično oblast (Liermann, 1967, str. 13).

Po Šinkovcu je politična stranka organizacija, ki neposredno deluje pri oblikovanju politične volje $v$ ljudskem zastopništvu, zaradi česar je tudi udeležena na volitvah, gre pa tudi za trajno organizacijo, tj. ne za ad hoc združbo (Šinkovec, 1997, str. 17).

Med označene opredelitve, ki so $v$ teoriji generično poimenovane s sintagmo "legitimacijske opredelitve", sodi tudi klasična definicija Edmunda Burka, po kateri je politična stranka označena kot skupina ljudi, ki se združuje zato, da bi s svojim skupnim trudom (nastopom) pospeševala javni interes, opirajoč se na določena načela, glede katerih se vsi strinjajo.

Legitimacijske opredelitve najdemo še pri kopici drugih avtorjev (teoretikov $\mathrm{s}$ tega področja), in sicer pri Mengerju (1952, str. 160), Henkeju (1991, str. 8), ter Marcicu, če se omejimo zgolj na avstrijsko-nemško področje (1967, str. 24).

Tovrstne opredelitve so po mnenju mnogih in problematične, ker ne obstaja objektivno merilo, ali cilji posamezne politične stranke zares upoštevajo splošno voljo nacije. Poleg tega pa ostaja ugovor, da imajo tudi preostala interesna in druga združenja za svoje cilje identično trditev, češ da so enako skladne s tako supraponirano voljo, kot to domnevno velja za politične stranke, zaradi česar tak razlikovalni definicijski dejavnik ne more več logično biti differentia specifica, na podlagi katere bi jih bilo mogoče medsebojno razlikovati.

Po Gradu je boj za oblast najpomembnejša in najznačilnejša prvina politične stranke, ki jo bistveno razlikuje od drugih organizacij oziroma združenj. Po njegovi definiciji štejejo za politične stranke samo tista združenja, ki imajo politične cilje, obvezno določene $v$ programu politične stranke. Po njegovem za politično stranko ni mogoče šteti združenja, ki se ne zavzema za politične cilje, pa tudi ne tistega, ki se sicer zanje zavzema, vendar pa ti niso izrecno navedeni $\vee$ programu politične stranke, kjer je mesto za določitev tovrstne politične razvidnosti (Grad, 1996, str. 5).

Grad nadalje zahteva obstoj še dveh konstitutivnih elementov, ki morata biti podana pri združenju, če hoče uspešno pretendirati na položaj politične stranke, in to je izpolnjen pogoj demokratičnega konteksta samooblikovanja politične volje na eni in aktivna vloga pretendentke za strankarski status, da sama predlaga kandidate na volitvah za politične (državne in subdržavne) sestope, po drugi strani.

Do podobnega izida pridemo, če vzamemo kot konstitutivni definicijski element kar postulat, da mora pretendentka za statusni položaj politične stranke izpolnjevati specifičen pogoj, in sicer da mora imeti strankarski program.

Program politične stranke omogoča volivcem zgolj enostavnejšo prepoznavnost politične stranke in s tem olajšuje volilno odločitev, logično gledano pa program vendarle ni neizogibno potreben. Politične stranke se lahko konkretno sprotno opredeljujejo o tekočih političnih vprašanjih in niso zato nič manj politične od strank, 


\section{Mik Strmecki}

\section{Pravni problemi regulacije področja političnih strank}

ki bi imele opredelitve vnaprej okvirno fiksirane $v$ svojih programih, saj ti ne morejo zajeti vsega, kar utegne prihodnost prinesti. Zato je taka zahteva logično nevzdržna.

Nekateri avtorji vendarle vztrajajo, da mora biti program politične stranke konstitutivni definicijski element njihove pravno-pojmovne opredelitve. Zlasti izstopa komentar Christiana-Friedricha Mengerja ter Maunza in Düriga. Slednji se opira v specifičnem nemškem primeru na prvi odstavek 3. člena nemškega področnega zakona o političnih strankah iz leta 1967, v katerem je navedeno, da so politične stranke vrste združenj, katerih cilji so vključeni v strankarske programe.

Nemška teorija in doktrina kljub temu večinsko stojita na stališču, da strankarski programi niso konstitutivni element pojmovne opredelitve politične stranke.

Pojmovna opredelitev politične stranke je $\vee$ pozitivnem pravu odvisna predvsem od tega, kako $v$ posamezni državi razumejo politiko $v$ razponu med državljanskim telesom in državno oblastjo.

Izhajajoč iz zakonske definicije pojma politične stranke $v$ našem področnem zakonu o političnih strankah (ZpolS, Ur. I. RS, št. 62/94, čl. 1), lahko sklepamo, da pojmovno ne spadajo $\vee$ pojem politične stranke interesna združenja, če ta neposredno ne sodelujejo na volitvah, zaradi česar torej tudi niso neposredno udeležena pri oblikovanju predpolitične volje ljudstva, ker je pogoj za kaj takega le neposredna postavitev lastnih kandidatov oziroma kandidatnih list na volitvah $v$ politične sestope na nacionalnem in/ali regionalnem, tj. evropskem in/ali občinskem oziroma znotrajnacionalnem regijskem/pokrajinskem/deželnem nivoju. Tukaj gre lahko za politične sestope predstavniškega značaja oziroma upravno-izvršilnega značaja, če se člansko popolnjujejo bodisi na podlagi volitev s pomočjo državljanske volilne pravi$\mathrm{ce}$, tj. na podlagi volitev od legitimiranega volilnega telesa, bodisi na podlagi kooptacije.

Pri političnih združenjih ločimo pomožne organizacije političnih strank, vzporedne organizacije političnih strank, nadomestne organizacije prepovedanih političnih strank in končno t. i. skrita, kriptopolitična združenja.

Pomožnim organizacijam političnih strank priznavamo status političnih strank. Pomožne organizacije političnih strank se delijo na delne in posebne organizacije, za katere velja pravo političnih strank kot lex specialis poleg zakona o društvih kot lex generalis, medtem ko za vzporedne oziroma stranske organizacije političnih strank velja zgolj društvena zakonodaja (tj. zakon o društvih). Delne organizacije političnih strank so v vertikalnem razmerju z matično politično strankarsko organizacijo, npr. mladinske sekcije strank, ki so tipičen primer kvalificiranih pomožnih organizacij političnih strank, medtem ko so posebne strankarske organizacije $v$ horizontalnem razmerju z matično strankarsko organizacijo. Z matično politično stranko so statusno izenačene naslednje entitete strank: delovne skupnosti političnih strank, strankarski strokovni odbori, strankarske šole, strankarski zavodi in strankarski gospodarski obrati, kot so npr. strankarske tiskarne in založbe. 


\section{Pravni problemi regulacije področja političnih strank}

Zanje torej veljajo pravice, privilegiji in dolžnosti kakor tudi vse omejitve, uveljavljene za politične stranke, kot to izhaja iz vsakokratne področne zakonodaje s področja političnih strank, ob predpostavki, da država tovrstno zakonodajo sploh ima. Anglosaške države take zakonodaje vsaj v obsegu, značilnem za evropske kontinentalne države, praviloma do sedaj niso imele, čeprav se tudi pri njih kažejo "kontinentalne" usmeritve.

Statusa politične stranke pa pravni red torej ne priznava vzporednim, tj. stranskim organizacijam političnih strank, kot so razni strankarski forumi in sosveti.

Pri razmejevanju med navedenimi različnimi pojmi si lahko pomagamo tudi s kriterijem, po katerem skušamo razmejiti t. i. bistvene sestavne dele političnih strank od t. i. pomožnih organizacij političnih strank. Najnazornejša metoda, ki jo lahko uporabimo za razmejitev omenjenih pojmov in nam $\vee$ največji meri poenostavi našo nalogo, je uporaba naslednjih kriterijev:

- kriterij prekrivanja članstva pomožne z matično organizacijo;

- kriterij stopnje finančne odvisnosti pomožne od matične organizacije;

- usklajenost ciljev med pomožno in matično organizacijo ter

- kriterij empirično ugotovljene stopnje organizacijske samostojnosti oziroma nesamostojnosti pomožne organizacije. Po tem kriteriju se štejejo za pomožne vse tiste strankarske organizacije (pojem "strankarske" je treba tukaj razumeti $v$ širšem smislu), ki pripomorejo k izvrševanju nalog političnih strank kakor tudi njihovih odgovornosti. Subsidiarno vlogo lahko pri tej analizi igra celo zavedanje članov organizacije o svoji resnični vlogi.

Strankarska področna zakonodaja je veljavna tudi za nadomestne organizacije prepovedanih političnih strank, zato so te še zlasti podvržene omejitvam iz naslova protiustavnega delovanja, ki sicer predvidevajo za politične stranke $v$ jurisdikcijskem smislu celo nekatere prednosti, saj so upravičene do t. i. privilegija, dodeljenega zgolj političnim strankam, po katerem jih sme obravnavati glede njihove eventualne prepovedi zaradi domnevnega protiustavnega delovanja izključno ustavnosodna instanca.

Takemu rezoniranju evropske pravne doktrine je treba vsekakor pritrditi, kajti če ne bi sledili logiki, da je treba nadomestnim organizacijam priznati strankarski pravni status, potem tudi ne bi bilo možno takšnih nadomestnih organizacij obravnavati pred ustavnim sodiščem v postopku, sproženem s ciljem njihove prepovedi zaradi očitka, da protipravno nadaljujejo že prej sodno obsojeno in prepovedano protiustavno dejavnost. Če bi se po drugi strani postavili na stališče, da nadomestna organizacija ni statusno politična stranka, bi jo lahko kvečjemu statusno degradirali $\vee$ običajno društvo, ki pa ga bi bilo mogoče policijsko prepovedati, kar bi bilo seveda pravno vprašljivo zaradi možnih zlorab.

Zgornji razpravi je treba dodati, da pravni red ne priznava statusa politične stranke "skritim, tj. kriptopolitičnim organizacijam", ki se nimajo niti najmanjšega namena 


\section{Mik Strmecki}

\section{Pravni problemi regulacije področja političnih strank}

potegovati za strankarsko-politični status, pa tudi javni interes države za kaj takega ne obstaja. Ob tem pa se je vendarle treba zavedati, da imajo kriptopolitične organizacije nekatere politične cilje, ki jih je objektivno gledano mogoče označiti kot protiustavne. Pojavne oblike takšne protiustavnosti prima facie so npr. razvidne iz okoliščine, da gre za kriptopolitično stranko, ki je bolj ali manj odvisna in/ali celo vodena od določene politične stranke, ki tega ne želi javno priznati, ker se npr. navidezno sama drži ustave, pri čemer ni pomembno, ali gre za domačo ali tujo nevidno roko, ki tako organizacijo usmerja. A fortiori velja povedano razlaganje za identifikacijo kriptopolitičnih strank tudi npr. pri organizaciji, ki bi jo, denimo, neposredno vodila tuja država, seveda s posredovanjem njenih organov (npr. neposredno preko svoje obveščevalne službe) ali pa pri organizaciji, ki bi jo obvladovala kakšna teroristična mreža. $\vee$ to kategorijo bi spadale novodobne strankarske celice raznih terorističnih tvorb.

Pred podobnimi izzivi verjetno zdaj stoji svet z nastopom verskega fundamentalizma ali kateregakoli drugega $v$ bistvenih znakih podobnega fundamentalizma, npr. rasno-evgenističnega, nacionalističnega, socialnega, tribalističnega itd.

$\mathrm{Na}$ to razpravo se navezuje tudi vprašanje prepovedi protiustavnega delovanja političnih strank, ki jih sme pravni red $v$ tistih državah $v$ Evropi, kjer ta institut sploh priznavajo, prepovedati edino, če obstaja prisiljujoči razlog, ki legitimira tak drastičen ukrep ustavnega sodišča. Ustavna sodišča smejo $v$ teh primerih upoštevati edino okoliščino, po kateri je politična stranka utemeljeno obtožena hude kršitve ustavnih norm pri svojem delovanju, če bodisi izraža $v$ svojem programu ali delovanju totalitarna nagnjenja ali pa stranka taka nagnjenja izraža npr. zaradi objektivnega pomanjkanja ustavno zaukazane notranje demokratičnosti $v$ njej ali če bi se izkazalo, da deluje zoper integriteto države, tj. zoper njeno neodvisnost oziroma celovitost.

Končno lahko pod določenimi pogoji spadajo med organizacije, ki jim pravni red ne priznava strankarskega statusa in jim ipso facto tudi odreka pravico do uživanja t. i. strankarskega privilegija, tudi razna društva prijateljev neke države, društva za kulturno sodelovanje z neko državo, društva, ki se nominalno zavzemajo za vrsto miru, itd.

Takšne skrite organizacije se smejo prepovedati po postopku, ki je uveljavljen za običajna društva, in torej zanje ne velja zakonodaja s področja političnih strank, s tem pa tudi ne, kar je najvažnejše, jurisdikcijski privilegij, dostopen le političnim strankam glede postopka, ki uravnava institut njihove eventualne prepovedi od ustavnega sodišča. Zaradi tega so skrite organizacije podvržene sankciji običajne policijske prepovedi od ministra za notranje zadeve iz naslova javnovarnostnega javnega interesa na podlagi ustreznih predpisov. Med temi predpisi je na prvem mestu kazenska in spremljajoča kaznovalna ter prekrškovna zakonodaja $\vee$ povezavi $z$ ustreznimi členi področnega zakona o društvih itd. 


\section{Mejniki v razvoju pravnega položaja političnih strank in vprašanje njihove konstitucionalizacije}

Še vedno je $v$ današnjih demokracijah precejšnja redkost, da pravni položaj političnih strank ustreza njihovemu dejanskemu pomenu in funkcijam na področju oblikovanja državnopravne politične volje. Po teoretiku Trieplu lahko razmerje države do političnih strank razdelimo na štiri obdobja oziroma faze: zatiranja, ignoriranja, priznanja in uzakonitve ter končno vključitve $v$ ustavo (Triepel, 1930, str. 8). V svetovnem merilu je urugvajska ustava iz leta 1917 prvi primer ustavne vključitve političnih strank (Marcic, 1967, str. 24), medtem ko je v Evropi do tega prišlo šele po 2. svetovni vojni. Italijanska ustava iz leta 1947 daje vsem državljanom ustavno garancijo svobodnega združevanja $\vee$ politične stranke, zato da bi $\vee$ demokratičnem delovanju sodelovali pri odločanju o državni politiki (Biscaretti di Ruffia, 1965, str. 764).

Paolo Biscaretti di Ruffia označuje politične stranke kot pomožne entitete države (enti ausiliari dello stato) in opisuje njihovo dejavnost kot zasebno izvrševanje javnih funkcij (un esercicio privato di pubblice funzionı). Italijanski pravni red daje $v$ bistvu državljanom le jamstvo svobodnega ustanavljanja političnih strank $\checkmark$ okviru svobode političnega združevanja (prav tam).

Nemška ustava iz leta 1949 gre vendarle nekoliko dalje od italijanske, kajti v prvem odstavku 21. člena bonskega temeljnega zakona ni zajamčeno samo svobodno ustanavljanje političnih strank, temveč je priznana strankam splošna pravica sodelovanja pri oblikovanju politične volje ljudstva, poleg tega pa ta člen zahteva tudi, da notranja ureditev političnih strank ustreza demokratičnim načelom in da morajo politične stranke dajati podatke o izvoru svojih sredstev.

$\checkmark$ drugem odstavku 21. člena nemške ustave je podana možnost prepovedi posameznih političnih strank, ki lahko sledi le na podlagi sodbe ustavnega sodišča. Naposled pa 21. člen nemške ustave vsebuje tudi zakonodajno napotitveno klavzulo, ki predvideva sprejem posebnega zakona za podrobnejšo ureditev področja političnih strank. Izčrpnost nemške ustavnonomotehnične obdelave materije političnih strank odpira vprašanje pomena "konstitucionalizacije" področja političnih strank v nemškem pravnem redu. Zlasti pomembno je tukaj vprašanje, ali so s tem politične stranke $\vee$ Nemčiji obravnavane kot organi države ali jih je treba še vedno razumeti kot institucije civilne družbe. Če se držimo Trieplove definicije državnih organov, katerih volja se šteje kot volja države, potem političnih strank nedvomno ne moremo šteti za državne organe (Triepel, 1930, str. 463).

Čeprav lahko brez težav empirično dokazujemo, da je državna volja v bistvu volja političnih strank, pa moramo vendarle priznati, da ta odvisnost ni utemeljena na pozitivnopravni podlagi in je zato brezpredmetna z vidika proučevanja pravnega položaja političnih strank. 21. člen nemške ustave $\vee$ bistvu priznava političnim strankam le pravico do sooblikovanja politične volje, s čimer ustava priznava političnim strankam vlogo pomembnega, čeprav ne edinega dejavnika $v$ tem procesu. 


\section{Mik Strmecki}

\section{Pravni problemi regulacije področja političnih strank}

Med druge dejavnike sodijo še tisk, radio, televizija in preostale oblike množičnega komuniciranja.

Po mnenju vodilnega nemškega teoretika Heringa sledi ravno iz načela svobodnega ustanavljanja političnih strank ( $v$ prvem odstavku 21. člena nemške ustave), da ustava nikakor ni imela namena politične stranke vključiti $v$ državni aparat. Svobodno formiranje je značilnost nedržavnih organov, medtem ko se državni organi formirajo po sili ustave in zakona in torej niso svobodne tvorbe (Hering, 1962, str. 63). Enakega mnenja kot Hering je tudi večji del pravne doktrine, kar je razvidno iz del številnih vodilnih nemških avtorjev s tega področja, kot so Hesse (1959, str. 27), Maunz in drugi (Maunz in drugi, 1991, str. 64), Heydte (1954, str. 468), Menger (1952, str. 160), Seifert (1975, str. 2), Scheuner (1952, str. 642) ter Heydte (Heydte 1954, str. 468). Nasprotnega mnenja sta Rabus (1996, str. 189) in Kaiser (1956, str. 236). Po mnenju Leibholza so politične stranke vgrajene $v$ državno sfero vsaj implicitno, čeprav se avtor po drugi strani oddaljuje od tega stališča, ker zatrjuje, da jih vsaj "za zdaj še ne moremo" šteti za državne organe, čeprav tega v prihodnosti ne izključuje (Leibholz, 1974, str. 72). Nemška teorija in judikatura sta se že zdavnaj oddaljili od Leibholzove doktrine.

Nasprotniki vključevanja političnih strank $v$ državni aparat navajajo kot nasprotni argument predvsem dejstvo, da politične stranke kot del državnega aparata ne bi mogle več ustrezno opravljati svojih funkcij $v$ razmerah demokratične ureditve (Hesse, 1959, str. 27). Doktrina se je poenotila $v$ naziranju, da je političnim strankam vendarle treba priznati poseben položaj nasproti državnemu aparatu glede na ustavnopravno priznavanje njihovih funkcij součinkovanja pri oblikovanju politične volje. Ravno iz citiranega posebnega ustavnega položaja političnih strank si je mogoče sploh razložiti poseben privilegiran način obravnavanja, po katerem je dana ustavnemu sodišču izključna pristojnost za preizkus zakonitosti njihovega delovanja oziroma si je mogoče razložiti vmešavanje pravnega reda $v$ njihovo notranjo organizacijo kakor tudi $v$ transparentnost njihovih financ. Pojmovni opis posebnega pravnega položaja političnih strank je bil zlasti močan izziv nemški teoriji in je sorazmerno zahtevna naloga, saj terja, da se podrobno seznanimo z judikaturo nemškega ustavnega sodišča $v$ zvezi s tem. Ustavno sodišče je $v$ svojih številnih sodbah različno opisovalo in opredeljevalo položaj političnih strank. Enkrat $v$ obliki dikcije, da politične stranke izvajajo funkcije ustavnega organa (B.Verf.GE št. 2 (str.27), (str.30); št. 5 (str.85), (str.34)), medtem ko $\vee$ eni redkejših sodb povezuje politične stranke in volilno pravico ter na tej podlagi označuje politične stranke kot kreacijske organe v smislu definicije Georga Jellineka (B.Verf.GE št. 1 (208), (224)).

Preobrat je sodba nemškega ustavnega sodišča iz leta 1966, kajti sodišče tukaj prvič uporabi sintagmo, da so politične stranke svobodne kolektivne tvorbe, ki izvirajo iz družbenopolitičnega področja civilne družbe (B.Verf.GE št. 56 (101); 1 (208); 3 (383), (393)). Po Liermannu in številnih drugih avtorjih pomeni citirana sodba 
iz leta 1966 prelomnico, ki je povsem jasno zakoličila položaj političnih strank izven državnega aparata (Liermann, 1967, str. 595).

Vsa ta judikatura nemškega ustavnega sodišča ni veliko pripomogla $k$ dokončni razjasnitvi pravnega položaja političnih strank $\vee$ Nemčiji. Von Mangold in Klein zamerita dikciji ustavnega sodišča, po kateri imajo politične stranke funkcije ustavnega organa, zlasti to, da je mogoče citirano sintagmo razumeti na različne načine, celo če se zanemari dejstvo, da ustava sama po sebi ne more imeti nikakršnih organov (Mangold in Klein, 1957, čl. 21).

Po mnenju Ridderja pomeni termin ustavni organ priložnostno in prehodno rešitev, kajti celo ustavno sodišče se je nazadnje ustrašilo lastne dikcije, da je ne bi kdo razumel kot vključitev političnih strank $v$ državni aparat (Ridder, 1965, str. 38). Christian-Friedrich Menger je za ponazoritev pravnega položaja političnih strank priredil iz upravnega prava poznani pojem javnopravnih ustavnih pristojnosti, ki jih zasebnopravni subjekt, $v$ tem primeru politična stranka, izvršuje ex proprio vigore $v$ svojem imenu (Menger, 1952, str. 160). Vprašati se je treba, ali daje 21. člen nemške ustave podlago naziranju, da gre pri političnih strankah in njihovem sodelovanju pri oblikovanju politične volje za izvrševanje ustavnopravnih pristojnosti. Komisija za preučitev položaja političnih strank $v$ Nemčiji je z večino glasov sprejela stališče, da so politične stranke svobodne tvorbe družbenega značaja, katerih javni položaj je $v$ državi sicer priznan (poročilo nemškega Bundestaga o političnih strankah iz leta 1968). Scheuner posebej poudarja, da politične stranke niso del državne organizacije, čeprav pripadajo javni sferi (Scheuner, 1952, str. 642).

Po Heringu so politične stranke pojmovno izenačene $z$ društvi z javnimi nalogami, medtem ko njihov vmesni položaj med državo in ljudstvom najbolje ponazarja njegova označitev političnih strank kot tvorb, ki imajo za cilj osvojitev oblasti, zato da bi lahko vplivale na državno politiko (Hering, 1962, str. 102). Po mnenju Liermanna je $\vee$ nemški teoriji in doktrini prevladujoče stališče, da so politične stranke vmesna tvorba med ljudstvom in državno organizacijo (Liermann, 1967, str. 10), kar potrjujejo tudi številni drugi nemški avtorji, kot so Friesenhahn (1987, str. 248), Henke (1964, str. 80), Ridder (1965, str. 26), Maunz in drugi (Maunz in drugi, 1991, čl. 21) ter Mangold in Klein (1957, čl. 21).

Nemška teorija je mnenja, da je treba ustavnopravni položaj političnih strank gledati $s$ stališča, da so te $\vee$ bistvu tvorbe, ki s svojim svobodnim in trajnim součinkovanjem na oblikovanje politične volje ljudstva izvršujejo javne naloge, ki jim jih ustava nalaga in jih zato tudi ustrezno pooblašča (Friesenhahn, 1987, str. 248).

$\checkmark$ Franciji je prišlo do konstitucionalizacije političnih strank šele $\vee$ času $V$. republike s 4. členom francoske ustave iz leta 1958, po katerem je političnim strankam priznana pravica do udeležbe na volitvah, s čimer je po mnenju francoske teorije jasneje potegnjena črta $v$ nasprotju z Nemčijo $v$ zanikanju koncepcije strankarske 


\section{Mik Strmecki}

\section{Pravni problemi regulacije področja političnih strank}

države (Kheitmi, 1984, str. 304). Po besedah Mohameda Kheitmija so politične stranke privatna združenja, ki izvajajo dejavnosti javnega interesa (prav tam, str. 311).

Avstrijska teorija se zaveda, da ustava strictu iure ne priznava izrecne soudeležbe političnih strank $v$ procesu oblikovanja politične volje ljudstva, čeprav očitno razume demokracijo kot politično strankarsko demokracijo po besedah Fridericha Koje in zato obstoj političnih strank predpostavlja (Koja, 1967, str. 22). Še dalje gre teoretik Kafka, po čigar mnenju se pravna skupnost v moderni državi sploh ne more razumeti drugače kakor pravna skupnost političnih strank (Kafka, 1959, str. 101).

Povojna avstrijska judikatura političnih strank tudi ni več obravnavala kot običajne korporacije javnega prava in je s tem pravno vzela podlago korporativizmu, ki je bil značilen za prvo avstrijsko republiko (Adamovich, 1952, str. 46). Politične stranke so izenačene s korporacijami javnega prava edino še na področju davkov (Adamovich, 1952, str. 870), tako da jim teorija priznava položaj korporacij javnega prava sui generis. S tem so bili odpravljeni številni dotedanji dvomi in nejasnosti, ki so bili posledica predvojne avstrijske upravnopravne doktrine, prakse in judikature (Brunner, 1964, str. 205).

$\vee$ anglosaških pravnih ureditvah ne priznavajo splošne pravice do združevanja, zaradi česar si tudi politične stranke kot neinkorporirane splošno koristne organizacije ne morejo v lastnem imenu naložiti nobenih pravnih obveznosti, poleg tega pa tudi ne morejo posedovati nepremičnin. Končno politične stranke tudi ne morejo $\vee$ lastnem imenu pravnoveljavno sklepati pogodb (Oleck, 1980, str. 51).

V Veliki Britaniji politične stranke nimajo položaja pravnih oseb, zato jim pravni red ne priznava nikakršne pravne sposobnosti (Leonhard, 1975, str. 2). V Veliki Britaniji je zakonodaja sicer posredno priznala funkcijo političnih strank $v$ njihovi demokratični ureditvi s posebnim zakonom iz leta 1937, po katerem država plačuje vodjo opozicije (Ministers of Crown Act, 1937).

Ameriški pravni red, teorija in judikatura obravnavajo politične stranke kot organizacije za vodenje volilne kampanje in se mora temu primerno tudi njihov status podrejati zahtevam in okvirom te ozke definicije. To seveda močno odstopa od prevladujočega kontinentalnoevropskega pristopa na področju definiranja vloge političnih strank znotraj pravnega reda. V ZDA obstaja o področju političnih strank tako na zvezni ravni kot na ravni posameznih držav obsežna zakonska regulativa, ki se zlasti nanaša na postavljanje kandidatov in na financiranje. Na Švedskem so priznali funkcije političnih strank šele $v$ sredini šestdesetih let prejšnjega stoletja. 


\section{Pravna narava funkcij političnih strank kot determinacijski dejavnik konceptualizacije izhodišč državne regulacije njihovega financiranja, financiranja volilnih kandidatov in volilnih kampanj}

$\checkmark$ modernih razmerah sta obstoj in funkcija političnih strank neizogibno dejstvo, ki omogoča posamezniku minimalno dejansko, tj. tvorno sodelovanje pri udejanjanju demokracije kot vladavine ljudstva.

Številne naloge javnega značaja, ki jih na svoja pleča prevzemajo stranke, zahtevajo znatna finančna sredstva za svojo realizacijo, kar še zlasti velja za predstavitev političnih volilnih kandidatov na volitvah. Gre za eno izmed pomembnejših nalog političnih strank, ki terja precejšnja finančna sredstva, pri čemer je ta faza pomemben del procesa oblikovanja politične volje ljudstva, kajti le tako so volivci lahko seznanjeni s temeljnimi premisami volilne odločitve, ki naj bi pomenila pretehtano izbiro, ne pa glasovanja na slepo.

Politične stranke morajo zato volivce seznanjati s svojimi temeljnimi političnimi programskimi usmeritvami ter kandidati, ki bodo takšne usmeritve zastopali.

$\checkmark$ dejavnost političnih strank sodi tudi seznanjanje ljudi z njihovimi idejami in sprotno opredeljevanje do aktualnih političnih vprašanj, tudi $\vee$ času trajanja parlamentarnega obdobja, tj. med predhodnimi in naslednjimi volitvami. Švicarski pravni teoretik Imboden trdi, da kolikor težje se državljansko telo dokoplje do bistva zadev, ki so za volitve relevantne in za katerih ozadje je potreben znaten intelektualen napor, toliko večji je pomen političnih strank $v$ vlogi pomoči ljudem pri opredeljevanju do aktualnih političnih vprašanj in zlasti kontroverznih dilem (Imboden, 1962, str. 32).

$\checkmark$ današnjem času postaja vse pomembnejša tudi opremljenost političnih strank z usposobljenim strokovnim in celo znanstvenim kadrom, skupaj z ustrezno infrastrukturo (prav tam, str. 84). Politične stranke potrebujejo zato svoj posebni strokovni aparat, ki omogoča strokovno podporo svojim poslancem oziroma poslanski skupini v parlamentu, da se lahko uspešno kosajo z vse bolj zapletenimi strokovnimi problemi. Le s pomočjo takšnega strokovnega aparata si je danes sploh mogoče zamisliti opravljanje predlagalne funkcije kot ene izmed temeljnih poslanskih funkcij, kajti $v$ nasprotnem primeru so poslanci enostavno prisiljeni vse to pomembno akcijsko polje prepustiti vladi in njenemu strokovnemu aparatu, s čimer se izniči sistemska vloga opozicije (Eichenberger, 1959, str. 155). Sistemska vloga opozicije je posledično seveda pogoj za funkcioniranje svobodne demokratične pravne države.

Ravnodušnost pravnega reda do tega, ali imajo politične stranke sploh dovolj sredstev za opravljanje svojih in hkrati javno koristnih nalog ter od kod si potrebna sredstva priskrbijo, je popolnoma nedopustna glede na osrednje mesto političnih 


\section{Mik Strmecki}

\section{Pravni problemi regulacije področja političnih strank}

strank $v$ procesu oblikovanja politične volje ljudstva $v$ svobodni demokratični pravni državi.

Za opravilno sposobnost moderne demokratične pravne države je zlasti pomembno, da se zagotovijo na pravno ustrezen način pravično urejeni viri in načini financiranja političnih strank glede na funkcionalno vlogo, ki jim jo pravni red dodeljuje. Vsekakor $\vee$ demokratični pravni državi še zdaleč ni nepomembna vloga političnih strank kot svojevrstnih katalizatorjev, ki pripomorejo h kristalizaciji mnenj in stališč. Te je treba iz prvotnega stanja času, kontekstu in prostoru primerno prečistiti, konceptualizirati in artikulirati, da bi dosegli ustrezno politično učinkovitost.

Tej vlogi, ki še posebej pride do izraza v volilni kampanji, pravzaprav ustreza način financiranja, ki angažira čim večje število državljanov, ki naj bi bili po možnosti še člani politične stranke (Weinmann, 1990, str. 137).

Po Eichenbergerjevem mnenju je le s takšnim načinom financiranja po eni strani mogoče zagotoviti udejanjenje želene integrativne funkcije političnih strank na področju oblikovanja politične volje ljudstva, po drugi strani pa je to edini način za preprečitev tega, da bi politične stranke postale same sebi namen, ne oziraje se na članstvo. Edino tak način financiranja zagotavlja, da se politične stranke ne bodo izneverile svoji instrumentalni vlogi pri oblikovanju politične volje ljudstva $\vee$ okviru svobodne demokratične pravne države (Eichenberger, 1959, str. 155).

Eichenberger celo zatrjuje, da je opisani, na članstvo osredotočeni sistem financiranja nemara še boljše jamstvo od načela znotrajstrankarske demokracije za to, da se politične stranke ne bi odtujile od ljudstva kot strankarske baze in postale osamosvojen center moči (prav tam, str. 232). Isto je trdil nekoliko starejši švicarski teoretik s področja političnih strank Duverger, in sicer da je za masovne politične stranke značilno, da se želijo z obračanjem na čim širšo javnost na področju financiranja postopno osamosvojiti od velikih donatorjev na tem področju.

Resničnost strankarskopolitičnega financiranja pa bolj ali manj $\vee$ nobenem primeru ne ustreza postuliranemu idealu. Številne politične stranke se $v$ svetu pogosto izdatno financirajo iz sredstev donatorjev, ki obsegajo neznaten delež državljanskega volilnega telesa, in/ali pa jih financirajo tudi podjetja ter interesna združenja. Vrh tega se celoten proces financiranja političnih strank pogosto odvija $\vee$ največji tajnosti in daleč od oči javnosti, zato ne preseneča, da pogosto prihaja do nezakonitosti in celo do koruptivne prakse na tem področju (prav tam). Tovrstna negativna praksa ni nevarna zgolj zaradi paralizirajočih posledic za same politične stranke, ki s tem izgubljajo svojo integrativno vlogo pri vključevanju čim večjega kroga ljudi v politično dogajanje oblikovanje politične volje, ampak se s tem politične stranke tudi izpostavljajo nevarnosti nenadzorovanih in s tem nedemokratičnih vplivov na oblikovanje politične volje ljudstva, tako navznoter kakor tudi navzven. Prekomerna regulatorna orientacija $\vee$ korist donacijskega načina financiranja političnih strank, zlasti če gre $v$ resnici za netransparentno pretakanje sredstev, utegne privesti 
do kompromitacije z ustavo deklarirane pravne enakosti kot enega bistvenih temeljev demokratične pravne države.

Pravni redi številnih demokratičnih držav so se od zadnje četrtine prejšnjega stoletja naprej začeli na regulativni ravni izčrpno ukvarjati s problematiko političnega financiranja predvsem zato, ker je prodrlo $v$ zavest spoznanje, da je financiranje političnih strank izjemno pereče načelno vprašanje, in tudi zaradi povsem neposrednega strahu oziroma skrbi, da ne bi bile politične stranke iz eksistenčne nuje, ob pomanjkanju ustrezne pravne regulacije na tem področju, prisiljene poseči po rešitvah, ki bi postavile pod vprašaj njihovo funkcijsko poslanstvo sodelovanja pri oblikovanju politične volje ljudstva in s tem svobodni demokratični javni red pravne države.

\section{Sklepne ugotovitve}

Glede kategorizacije funkcij političnih strank lahko ugotovimo, da je celotno funkcijsko področje političnih strank mogoče razčleniti v tri razločevalne kategorizacijske sklope, izhajajoč pri tej razdelitvi iz kriterija kontinuuma, ki se razteza od nedvomno javnopravnih funkcij preko napol javnopravnih funkcij do povsem nejavnopravnih funkcij političnih strank. Javnopravne funkcije opravljajo politične stranke $v$ javnem interesu, pri čemer se javnopravne funkcije pojmovno prekrivajo $s$ katalogom nalog, ki izhajajo iz funkcije oblikovanja t. i. "državne politične volje".

Pojem oblikovanja državne politične volje obsega poleg delovanja političnih strank $v$ parlamentu tudi funkcijo organiziranja delazmožne vladne pozicije oziroma opozicije tej. Poleg naštetega spada $v$ javnopravni sklop strankinih funkcij pogojno tudi funkcija kandidiranja volilnih kandidatov ob pogoju, da je $v$ dani državni ureditvi uveljavljen strankarski kandidacijski monopol. $\vee$ to kategorijo funkcij spada tudi funkcija izobraževanja političnega nosilnega kadra, predvidenega $v$ okviru priprav na zasedbo in prevzem ustrezne kvote javnih političnih funkcij.

Javnopravne funkcije je upravičeno oziroma največkrat kar nujno financirati iz proračuna, ker gre za funkcije, ki so ključnega pomena za ohranitev opravilne sposobnosti večstrankarskega sistema. Ta je oprt na pluralistični demokratični konkurenčni boj za volilne glasove na volitvah, umeščenih $v$ cel splet pravnih institucij pravne države, ki naj omogočijo tovrsten fair play.

Drugo kategorijo tvori sklop t. i. napol javnih funkcij političnih strank, kar se deloma prekriva s katalogom funkcij $v$ okviru nalog, povezanih z oblikovanjem ljudske politične volje, tj. z oblikovanjem oziroma sooblikovanjem državljanske avtonomne volje t. i. državotvornega ljudstva $\vee$ fazi, ko te še ne moremo označiti kot "državno voljo". Ta se formira šele $\vee$ parlamentu in $v$ organih, ki jim daje legitimnost. 


\section{Mik Strmecki}

\section{Pravni problemi regulacije področja političnih strank}

Političnim strankam ni priznan $v$ pravu nikakršen monopol na oblikovanje ljudske politične volje, zaradi česar si to svojo vlogo politične stranke delijo z drugimi za to poklicanimi subjekti, npr. mediji, različne javnopravne in zasebne korporacije, npr. razne zbornice, od splošnejše gospodarske do poklicnih, ter verske, humanitarne in nevladne organizacije, različne ustanove (fundacije), sindikati itd.

Ker to področje, tj. oblikovanje ljudske volje, ni pridržano izključno političnim strankam, je tudi samo po sebi razumljivo, da ne moremo verodostojno pravno razglasiti te funkcije kot javnopravne. Če bi to naredili, bi po isti logiki to morali priznati tudi drugim udeležencem pri oblikovanju ljudske politične volje, kar bi bil seveda nesmisel $\vee$ pomenu argumentum ad absurdum, zlasti če si predstavljamo še finančne posledice.

$\checkmark$ praksi številnih držav je dejansko uveljavljena državna alimentacijska dolžnost tudi za pokrivanje stroškov $v$ zvezi z oblikovanjem oziroma sooblikovanjem ljudske politične volje $v$ tistem segmentu, za katerega skrbijo politične stranke. Za to anomalijo se ad hoc išče razlog z namenom upravičenja oziroma neka pravna podlaga, ki naj bi upravičevala takšno državno alimentacijo funkcije, ki ni opredeljena kot javnopravna, in da se s tem ne bi odprla ista možnost drugim akterjem na tem področju. Prisiljujoč razlog je po našem mnenju mogoče edino verjetno najti in obrazložiti, opirajoč se na državno skrb, uresničeno s političnimi strankami v obliki nekakšne podaljšane roke države, da ta vloži ustrezna sredstva, tudi javnofinančna, in zaradi pomanjkljive finančne podstati tega sistema, ki se npr. ne more več obdržati pri življenju iz lastnih moči, prepreči razkroj opravilne sposobnosti večstrankarske demokracije, če bi se izkazalo, da je sicer ogrožena eksistenca oziroma veljavnost načel, na katerih ta demokracija sloni. To je tudi edini način, na podlagi katerega je še mogoče za silo upravičiti uvrstitev teh funkcij med varovane objekte pravne države in jih zato tudi alimentirati iz proračuna.

Tretja kategorija funkcij je pa z javnopravnega vidika povsem brezpredmetna, ker gre za povsem zasebno dejavnost političnih strank, povezano z njihovo založniško in publicistično-knjigotržno dejavnostjo, pri kateri bi bila državna alimentacija zanesljivo absurdna.

\section{Literatura}

- $\quad$ Adamovich, Ludwig, Verwaltungsrecht, 2. del, Domus Verlag, Wien, 1952.

- Biscaretti di Ruffia, Paolo, Diritto costituzionale, 7. izd., Editioni Zambini, Napoli, 1965.

- Brunner, Erich Edwin, Die Problematik der verfassungsrechtlichen Behandlung extremistischer Parteien in den Westeuropäischen Verfasssungsstaaten, Müller Verlag, Zürich, 1964.

- Duverger, Maurice, Die politische Parteien, Nomos verlag, Tübingen, 1959

- Eichenberger, Kurt, Die oberste Gewalt im Bunde, Schindler Verlag, Bern, 1959.

- Friesenhahn, Ernst, Die verfassungsrechtliche Stellung der Parteien in der Bundesrepublik Deutschland, članek v reviji Zeitschrift fur Staatsrecht ZSR NF 87/I, 1987. 


\section{Pravni problemi regulacije področja političnih strank}

- Grad, Franc, Državna ureditev Slovenije, Državna založba Slovenije, Ljubljana, 1996.

- Grewe, Wilhelm, Zum Begriff der politischen Partei, znanstvena razprava, Festgabe für Erich Kaufmann, zbornik, Stuttgart/Köln, 1950.

- Henke, Wilhelm, Das Recht der Politischen Parteien, Delphi verlag, Göttingen, 1964

- Henke, Wilhelm, Das Recht der politischen Parteien, 3. izd., Nipperdey Verlag, Bonn, 1991.

- Hering, Wolfgang, Zur Frage der Anerkennung der politischen Parteien als Staatsorgane, Nomos Verlag, Mainz, 1962.

- Hesse, Konrad, Die Verfassungsrechtliche Stellung der Parteien im modernen Staat, znanstvena razprava, Veröffentlichungen der Vereinigung der Deutschen Staatsrechtslehrer, zbornik, zvezek 17, Walter de Gruyter Verlag, Berlin, 1959.

- Heydte, F. A. von der, Freiheit der Parteien, v: Die Grundrechte, 2. izd., Neuman/Nipperdey/Scheuner, Berlin, 1954.

- Imboden, Max, Die politischen Systeme, Heller Verlag, Basel und Stuttgart, 1962.

- Kafka, Gustav E., Die Verfassungsrechtliche Stellung der Parteien im modernen Staat, separat v zborniku WVSt.L, zvezek 17, Walter de Gruyter Verlag, Berlin, 1959.

- Kaiser, Josef H., Die Repräsentation organizierter Interessen, Walter de Gruyter Verlag, Berlin, 1956.

- Kelsen, Hans, Vom Wesen und Wert der Demokratie, 2. izd., J. C. B. Mohr Verlag, Tübingen, 1929.

- Kheitmi, Mohamed Rechid, Les partis politiques et le droit positif français, Editions Gallimard, Paris, 1984.

- Koja, Friedrich, Die Bundesverfassung und die politischen Parteien. Österreichische Monatshefte, 1967.

- Leibholz, Gerhard, Das Wesen der Rapräsentation und der Gestaltwandel der Demokratie im 20. Jahrhundert, 3. izd., Walter de Gruyter Verlag, Berlin, 1966.

- Leibholz, Gerhard, Parteienstaat, Walter de Gruyter Verlag, Berlin, 1969, str. 106.

- Leibholz, Gerhard, Strukturprobleme der modernen Demokratie, 3. dop. izd, Verlag Suhrkamp, Frankfurt/a.M., 1974.

- Leibholz, Gerhard, Verfassungsrechtliche Stellung und innere Ordnung der Parteien, znanstvena razprava v zborniku, Verhandlungen des 38. Deutschen Juristentages, Tübingen, 1951.

- Leohard, Dick R. L., Paying for Party Politics, separat, Political and Economic Planning, zbornik, London, 1975.

- Liermann, Eberhard, Modelle der Parteienfinanzierung und ihre Verfassungsmässigkeit, Alpha Verlag, München, 1967.

- Löwenstein, Karl, Staatsrecht und Staatspraxis der Vereinigten Staaten, Berlin/Heidelberg, 1959

- Mangold, Hermann von, Klein, Friedrich, Das Bonner Grundgesetz, 2. izd., Verlag Suhrkamp, Frankfurt/Berlin, 1957.

- Mangold, Hermann von, Klein, Friedrich, Das Bonner Grundgesetz, 6. del, Vahlen, München, 1991.

- Marcic, Rene, Sentenzen zur Parteienfinanzierung, članek v reviji "Österreichische Monatshefte", 1967.

- Maunz, Dürig, Herzog, Scholz, Grundgesetz - Kommentar, 2. del, Loseblattsammlung, C. H. Beck Verlag, München, 1991. 


\section{Mik Strmecki \\ Pravni problemi regulacije področja političnih strank}

- Menger, Christian-Friedrich, Zur Verfassungsrechtlichen Stellung der politischen Parteien, separat, Revija Annalen des Öffentlichen Rechtes, Tübingen, 1952.

- Menzel, Eberhard, Staatliche Parteifinanzierung in modernen Parteienstaat, znanstvena razprava, zbornik, DOV, Karlsruhe, 1970.

- Ogris, Albin, Politične stranke, samozaložba, Ljubljana, 1927.

- $\quad$ Oleck, Howard L., Non-profit Organizations and Corporations, Englewood Cliff, New Jersey, 1980.

- Plate, Heiko, Parteifinanzierung und Grundgesetz, Schriften zum Öffentlichen Recht 30. del, Berlin, 1986

- Rabus, Günther, Die innere Ordnung der politischen Parteien im gegenwärtigen Deutschen Staatsrecht, Hickel R. Verlag, München, 1996.

- $\quad$ Ridder, Helmuth, Grundgesetzwidrige Wettbewerbbeschränkungen im politischen Prozess durch Staatliche Direktfinanzierung der politischen Parteien, članek, zbornik, Festschrift für Franz Böhm, Aachen, 1965.

- Scheuner, Ulrich, Der Bereich der Regierung, separat v zborniku Festschrift für Rudolf Smendt, Delphi Verlag, Göttingen, 1952.

- Seifert, Karl-Heinz, Die politischen Parteien im Recht der Bundesrepublik Deutschland, Heymanns Verlag, Köln/Berlin/Bonn/München, 1975.

- Sorauf, Franz, J., Party Politics in America, 4. izd., Chapel Hill, Boston/Toronto, 1980

- Šinkovec, Janez, Pravice in svoboščine, časopisni grafični zavod Uradni list Republike Slovenije, Ljubljana, 1997.

- Triepel, Heinrich, Die Staatsverfassung und die politischen Parteien, 2. izd., Manzsche Verlag, Wien, 1930

- Weinmann, Roland, Die Finanzierung politischen Parteien im Steuerrechtlicher Betrachtung, C. H. Bech Verlag, München, 1990.

\section{Judikaturna gradiva}

- Odločba avstrijskega zveznega ustavnega sodišča z dne 8. 3. 1947.

- Odločba nemškega zveznega ustavnega sodišča, B.Verf. GE št. 4 (27), str. 30, št. 5 (85), (134).

- Odločba nemškega zveznega ustavnega sodišča B.Verf. GE št. 1 (208), (224), precedenčna sodba.

- Odločbi nemškega zveznega ustavnega sodišča B.Verf. GE št. 20 (56), (101), št. 3 (383), (393).

\section{Ustavna in zakonska gradiva}

- Ministers of Crown Act iz leta 1937 (1 Edv. 8 \& Geo. c. 38).

- Grundgesetz der Bundesrepublik Deutschland vom 23. 5. 1949.

- Ustava Republike Slovenije, Ur. I. RS, št. 33/91, 47/97, 66/00, 24/03.

- Zakon o političnih strankah, Ur. I. RS, št. 62/94, 13/98, 1/99, 24/99, 70/00, 51/02, 94/02.

- Zakon o političnih strankah Zvezne republike Nemčije, B.G.BL. I.s. št. 773/67, 1538/79, 1481/83, 897/87, 2615/88, 142/94, 149/94, 146/98.

Doc. dr. Mik Strmecki, doktor pravnih znanosti, je zaposlen kot docent na Fakulteti za upravo Univerze v Ljubljani za področje javne uprave. Leta 1996 je pridobil tudi naslov magistra ekonomskih znanosti s področja menedžmenta (MBA). Dr. Strmecki ima opravljen pravosodni izpit in je stalni sodni tolmač za angleški jezik. 


\section{SUMMARY \\ Legal problems concerning the regulation of political parties in Slovenia and in the E.U.}

The article addresses various issues connected with the overriding concern the state has to tackle when facing the prospect of regulating in the domain of political parties acting as a vehicle for the effective exercise of free speech in political matters of public concern. One of such matters that needs to be tackled at the outset is foremost to come forward with a meaningful definition of the legalistic notion of a political party for obviously practical reasons so as to be able to judge from such a definition the ambit, which is to be covered by the legal norms, contained in statutes dealing with political parties. Such norms cover conditions set out for the registration of political parties along with their relevant essential, i.e. core functions, their legitimate activities, their legitimate sources of finance, the rules pertaining to voluntary dissolution of parties, etc. These norms also cover the so-called party privilege along with the criteria of its application and/or its inapplicability and also the termination of its applicability. This privilege means just a jurisdictional privilege, by force of which, exclusively the constitutional court is empowered to rule on the unconstitutionality and/or illegality of a given political party and thus on its dissolution, which in consequence also means the extinction of its legal personality as a final possible sanction. In case a political party's activity is pronounced as prohibited and also its mouthpiece, i.e. such political party is banned, its legal personality is ruled out of its existence and its assets are confiscated.

There is an outline of a list of definitions proposed by legal theory and doctrine.

Furthermore, there is a lengthy description of various criteria, which could be utilized to differentiate between the core party organization, which has the benefit of enjoying the political party privilege on one hand, and other party organizations not endowed with this privilege, because of the simple fact that such entities, though in one way or another being connected to the core political party, are denied this privilege precisely for the reason that they cannot be logically considered as central enough to the task of exercising the party's functions. Political party freedom is legally considered as a functional sort of freedom, which should therefore take such functions seriously into consideration, when devising criteria for the delineation of the core party organization from other entities not deserving to be considered as such, which 
Mik Strmecki

Pravni problemi regulacije področja političnih strank

consequently means that the law on political parties cannot be applied to such an organization, which means, in extenso that such an organization could be banned by a simple Decree of the Minister of Interior or the Minister of Justice, as the case may be in any given country.

Taking as a point of departure a given definition, the legitimate core functions political parties are supposed to perform are summarised and then compared to the outcome, according to the various laid down definitions. These functions are cathegorised according to the need of their being subsidized by the state budget. 